\title{
ТЕОРІЯ СОЩАЛЬНИХ РОЛЕЙ В КОНЦЕПЦІї СОЦАЛЬНОӤ ВЗАЕМОДІЇ Т. ПАРСОНСА ТА ЇЇ ВПЛИВ НА ВИВЧЕННЯ СОЦІАЛЬНОЇ АДАПТАЦІї ОСОБИСТОСТІ
}

У статті розкривається поняття соціальної ролі по Парсонсу. Автор підкреслює, що ролі у Парсонса інституціональні, якщо вони повністю узгоджуються 3 встановленими культурними зразками, причому виділення ролі актора з усієї системи його особистості робить можливим аналіз взаємозв'язку особистості з соціальними системами. Автор відмічає, що процес засвоєння індивідом соціальних ролей, що здійснюється в ході соціалізації особистості по Парсонсу, включає в себе три основних компоненти. Перший з них полягає у вигляді прийнятних для даного суспільства і даної сукупності ролей в цьому суспільстві орієнтирів поведінки. Другій - є надання суспільством індивіду сприятливих для нього умов діяльності відповідно до продиктованих йому (або обираються їм самим) ролей. Третій - $є$ дотримання виконання індивідами належних рівнів лояльності по відношенню до колективних інтересів і потреб. Тобто Т. Парсонс вважав, що саме в процесі соціальної взаємодії виникають i реалізуються соціальні ролі індивідів.

Ключові слова: соціальна роль; соціальна структура; інституціоналізація; соціальна система; диспропорції потреб; рольові очікування; інтерналізація

Постановка завдання. Аналіз роботи Т.Парсонса "Про структуру соціальної дії" в умовах глобалізації суспільних і інформаційних процесів, які призводять до швидкої зміни об'єктивної реальності, що значно ускладнює адаптацію людини в суспільстві, показує оптимальні шляхи для соціалізації особистості. Для Українського суспільства дана проблема ще більш актуальніша, бо воно знаходиться на переломному етапі свого становлення.

Мета дослідження - Визначити вплив теорії соціальних ролей Т.Парсонса на вивчення процесу соціалізації особистості.

Завдання дослідження. Визначити поняття ролі за Парсонсом;

- показати взаємозв'язок між соціальною роллю і соціальною структурою;

- розкриття змісту поняття "інституціональної ролі" та його функцій;

- визначення понять " диспозиції потреб" і "рольових очікувань" та проблеми їх класифікації;

- розгляд соціальної системи як системи ролей, які адаптують особистість в суспільстві.

Виклад основного матеріалу. Роль як одиниця соціальної системи за Парсонсом розуміється, як система взаємодії множинності осіб, аналізована в рамках системи координат теорії дії. Безумовно, соціальна система складається 3 
взаємин індивідуальних акторів. Отже взаємини представляють собою такі сукупності діючих сторін, оформлених у вигляді відносин, в яких вони орієнтовані один на одного, враховують один одного. Для аналітичних цілей, як правило, найбільш важливою одиницею соціальної структури $є$ не конкретна особа, а ії роль.

"Роль - это такой организованный сектор ориентации актора, который конституирует и определяет его участие в процессе взаимодействия. Она включает набор взаимно соотнесенных ожиданий, касающихся действий как самого актора, так и тех, с кем он взаимодействует. И актер и те, с кем он взаимодействует, имеют такие ожидания". (Парсонс, 2000, с.194)

Ролі інституціональні, якщо вони повністю узгоджуються з встановленими культурними зразками та організовані навколо сподівання того, що актор буде конформен по відношенню до морально санкціонованих еталонів ціннісної орієнтації, визнаними членами спільності, в якій функціонує роль.

Виділення ролі актора $з$ усієї системи його особистості робить можливим аналіз взаємозв'язку особистості з соціальними системами. Структура соціальної системи і функціональні імперативи ії дії і збереження або ії упорядкованої зміни як системи відрізняються від структури та імперативів особистості. Проблеми особистості і соціальної структури можуть досліджуватися тільки тоді, коли ці поняття розрізняються. Лише в цьому випадку можливе вивчення зчленування і взаємозалежності особистості і соціальної системи.

Подальша відмінність між соціальною системою та системою особистості полягає в тому, що соціальна система не пов'язана 3 яким-небудь конкретним агрегатом організмів. Більш того, немає підстав вважати, що якщо, зазнавши змін персоналу, соціальна система залишається тією ж самою, нові актори, що замінили тих, які вибули, обов'язково у всіх деталях своїх особистостей тотожні своїм попередникам.

Приймаючи, що саме ролі, а не особистості $є$ одиницями соціальної структури, ми можемо зрозуміти необхідність деякого елемента «люфту»у відносинах між структурою особистості і виконанням ролі. Рольові ситуації можуть приймати для актора будь-які значення, які можливі для ситуацій загалом. Їх значення, що роблять вплив на мотивацію поведінки, будуть різні для різних особистостей. Але оскільки впорядкованість реакцій особистості суттєва для підтримки стабільності певного сектора соціальної системи, існують деякі «механізми контролю» для утримання потенційного різноманіття реакцій актора в більш вузьких межах, ніж ті, які визначаються простим поєднанням ситуації та особистості актора без уточнення рольових очікувань.

"Важной характеристикой большинства социальных ролей является то, что действия, необходимые для их выполнения, не предписываются во всех подробностях, а допустимым считается некоторый диапазон вариабельности. Отклонение в известных пределах не влечет санкций". (Парсонс, 2000, с.196) 
Цей діапазон свободи дозволяє акторам з різними типами особистостей в цілому відповідати очікуванням, пов'язаним з ролями, без надмірних напружень. Треба також зауважити, що рольові очікування санкції дійсно здійснюють вплив на індивідуального актора, який цілком може породжувати напруги, що мають значний вплив на різні типи особистостей.

Цей вплив здійснюється в таких діях, які в свою чергу викликають множину соціальних наслідків і часто призводять до розвитку нових механізмів соціального контролю, або породжують тенденцію до змін, або і те, і інше. При посередництві описаних механізмів особистість і рольова структура утворюють надзвичайно взаємозалежні системи.

На думку Парсонса: "Структура - это совокупность относительно устойчивых стандартизированных отношений между элементами." (Парсонс, 2000, c.176c.)

А оскільки елементом соціальної системи є актор, то соціальна структура являє собою стандартизовану систему соціальних відносин між акторами. Однак відмінна риса структур і систем соціальної дії полягає саме в тому, що в більшості відносин дійова особа не бере участі в якості цілісної сутності, а бере участь в них лише за допомогою даного диференційованого «сектора» своєї цілісної дії (в тому ж сенсі, в якому дана цегла як ціле є або не є «частиною» даної стіни). Отже, попереднє положення повинно бути пере формульоване: соціальна структура являє собою систему стандартизованих відносин акторів, що виконують ролі відносно один одного. Поняття ролі з'єднує підсистему дійової особи як психологічної одиниці з означеною соціальною структурою.

Тут виникають два питання. По-перше, яка природа цього зв'язку, що таке соціальна структура з точки зору актора, що виконує свою роль в ній? По-друге, яка природа «системи» стандартизованих відносин в соціальній структурі?

Ключ до відповіді на перше питання лежить в нормативноволюнтаристичному аспекті структури дії. 3 точки зору соціальної системи роль - це певний елемент узагальненої стандартизації дій індивідів, що входять в цю систему. Але це не просто статистична тенденція. Важливе значення тут мають категорії мети і стандарту. 3 точки зору актора його роль визначена нормативним очікуванням членів групи, сформованим в соціальних традиціях цієї групи. Наявність таких очікувань складає істотну особливість ситуацій, в яких знаходиться актор. Прийняття або неприйняття цих очікувань тягне за собою санкції схвалення і нагороди або осуду і покарання. Більше того, очікування складає частину його власної особистості. В процесі соціалізації ним засвоюються - більшою чи меншою мірою - стандарти та ідеали його групи, так що вони стають ефективними мотиваційними силами в його власній поведінці, незалежно від зовнішніх санкцій.

Рольові очікування, як було зазначено вище, $є$ центром як особистості, так i соціальної системи. Перш ніж ми перейдемо до класифікації цих одиниць, 
напевно, буде резонно коротко розглянути способи локаційного і інтегративного фокусування, як воно існує в системі відліку теорії дії. Ми повинні сказати, що системи дії - як актори, так і соціальні об'єкти - можуть бути і особистостями, і колективами: ті й інші є абстракцією від одних і тих же конкретних дій. Різні способи абстрагування використані в розведенні цих двох систем, оскільки безпосередньо з спостереження випливає, що особи і колективи мають різні способи локаційного і інтегративного фокусування. Інтегративне фокусування це, в деякому розумінні, принципи абстрагування, використовувані при розміщенні або обмеженні системи: так, індивідуальний організм інтегративний фокус соціальної системи. Інтегративне фокусування, отже, використовується для абстрагування самої соціальної системи від всієї сфери потенційних соціальних проблем.

"...существенным аспектом социальной структуры является система стандартизированных ожиданий, которая определяет правильное поведение личности, исполняющей некоторые роли, основанные как на ее собственных позитивных мотивах конформности, так и на санкциях других. Такие системы стандартизированных ожиданий, рассматриваемые по их месту в тотальной системе и достаточно глубоко пронизывающие действие, так что их можно принимать без доказательства как законные, условно называются «институтами»". (Парсонс, 2000, c.176)

Отже, основним структурним стабільним елементом соціальних систем, який, згідно викладених міркувань, повинен грати вирішальну роль в їх теоретичному аналізі, є структура інституційних стандартів, що визначають ролі акторів, що входять в неї.

"...институционализированные роли представляют собой механизм, интегрирующий весьма разнообразные возможности «человеческой природы » в единую систему, способную преодолеть ситуационные крайности, с которыми общество и его члены постоянно сталкиваются." (Парсонс, 2000, с.178)

Інституціональні ролі виконують дві функції по відношенню до цих можливостей. Перша полягає у відборі таких можливостей поведінки, які відповідають потребам і укладаються в межі даної стандартизованої структури, а інші типи поведінки при цьому придушуються. Друга функція забезпечує через механізми взаємодії максимум мотиваційної підтримки дії, яка відповідає рольовим очікуванням.

Друга основна проблема полягає в структурі самих інститутів як системи. Інститути розуміються як фактори, що контролюють дії людини в суспільстві. Отже, в якості системи вони повинні бути одночасно пов'язані як 3 функціональними потребами акторів - індивідів, так і з соціальними системами, які вони утворюють. Таким чином, основним структурним принципом, так само як і в анатомії, є принцип функціональної диференціації. Проте функціональний 
зміст в соціальних явищах виявляється більш складним, бо тут переплітаються функціональні потреби актора і соціальної системи.

Другий тип інститутів - інструментальні, що сформувалися заради досягнення цілком певних цілей. Наприклад, деяка дана процедура, на зразок тих, що застосовуються в сучасній медицині, здійснюється в рамках інституціональної ролі лікаря. Нарешті, по-третє, мають місце «інтегруючі» інститути, які орієнтовані перш за все на регуляцію відносин індивідів з метою уникнути конфліктів або добитися позитивної кооперації. Прикладами цього можуть служити соціальна стратифікація і влада.

Оскільки відносна оцінка особистих якостей і досягнень в соціальній системі неминуча, остільки вельми істотно, щоб ці оцінки інтегрувалися в упорядкованій системі ранжирування, в системі стратифікації суспільства. У той же час можливості відхиляється і необхідність детальної координації дій багатьох людей у всякому складному суспільстві такі, що не можна покластися на спонтанну реакцію, на неорганізований контроль. Деякі особи та організовані агентства повинні мати владу, щоб в певних межах придушити відхилення і його наслідки або сприяти ефективній кооперації. I знову досить істотно для інтеграції суспільства, щоб такий контроль над іншими був інституційно упорядкованим, регульованим і представляв собою систему ролей законної влади. Це важливий фактор ефективності контролю, бо він робить можливою апеляцію до почуття морального зобов'язання і дозволяє регулювати саму владу, яка в разі зловживання може привести до серйозних наслідків.

Однак динамічний аналіз неможливий тільки лише 3 точки зору систематичного розгляду інституційної структури. Для проведення такого аналізу необхідно ввести узагальнююче тлумачення поведінкових тенденцій акторів - людей в тій ситуації, в якій вони перебувають, підлягають впливу очікувань їх інституціональних ролей. У найзагальніших рисах таке узагальнення залежить від теорії «мотивації» людської поведінки.

Все це перш за все істинно в двох напрямках. Рання тенденція в психології розглядала «особистість» як вираз генетичної конституції або як єдину у своєму роді особистість. Проте вивчення соціалізації в порівняльній перспективі показує, що у тих, хто соціалізувався в одній і тій же культурній та інституційній системі, в «структурі характеру» існують значні елементи однаковості, варіюються в залежності від різних ролей усередині системи.

Хоча межі застосування цієї концепції структури ще не з'ясовані, все ж визнано ії загальне теоретичне значення. Там, де вона застосовується, стандарти мотивації, які зазвичай використовуються для пояснення поведінки в інституціональної ролі, не виводяться безпосередньо 3 «схильностей людської природи» взагалі. Вони залежать від компонентів, організованих в деяку особливу структуру. Сформований тип особистості буде мати свій власний стандарт мотивації і тенденції поведінки. 
Інший принциповий напрямок розвитку стосується області, яка розглядає процеси рухливості поведінки в будь-якій даній соціальній системі на психологічному рівні. Очевидно, особливо в результаті розгляду складних суспільств, що ці межі широкі для великих мас населення і що розподіл типів характеру, в більшій чи меншій мірі відповідають вимогам даної ролі.

Локаційне фокусування особистісних систем - це диспозиції потреб. Система особистості - в певному сенсі - формується з різних диспозицій потреб: кожна з них забезпечує задоволення тих чи інших потреб системи особистості. Диспозиції потреб відповідає ряд конкретних орієнтацій. Іншими словами, диспозиція потреб - це сутність, що отримується в результаті логічних міркувань, вона виходить в результаті осмислення послідовності, що спостерігається у виборі i, що виявляється в широкому колі різноманітних орієнтацій. Таким чином, коли ми говоримо про диспозиції потреб, іноді здається, що ми говоримо про якусь реальну сутність, що 3 певних причин контролює велику різноманітність орієнтацій i представляє їх утримання; в інших випадках виявляється, що ми говоримо про послідовні ряди орієнтацій. Логіки можуть вказати нам, що це - звичайне використання понять як взаємозамінних: з одного боку, виведена в результаті міркувань сутність, постульовано на підставі ряду даних i, з іншого - цей ряд даних сам по собі. Ця постульована сутність у певному сенсі - скорочений вираз для ряду даних, на підставі яких вона виведена.

"Локационный центр социальной системы — роли или ролевые ожидания. Социальная система в определенном смысле состоит из разнообразных ролей или ролевых ожиданий; каждая из них обеспечивает удовлетворение тех или иных потребностей социальной системы. Роли, так же, как и диспозиции потребностей, соответствует ряд ориентации; роль или ролевое ожидание - это сущность, выводимая точно таким же образом, как и диспозиция потребности. Каждая ориентация, соответствующая постулату, - одна из функций роли (которая частично контролирует ее), диспозиции потребностей (которая также частично ее контролирует), а возможно также и других факторов, не указанных здесь". (Парсонс, 2000, c.228).

Коли орієнтації відповідно згруповані до диспозиції потреб, яка їх обумовлює, і відповідно до індивідуального організму, який володіє цією диспозицією потреб, ми маємо справу з системою особистості. Коли орієнтації згруповані за ролями або рольовим очікуванням, які зумовлюють їх, і відповідно з групою взаємодіючих осіб, яким вони належать, ми маємо справу з соціальною системою.

Далі, оскільки жодна з цих більш глибоких змінних (локаційний центр та ін.) не надає іншого ефекту за винятком впливу на орієнтацію дії (яке не обов'язково буває свідомим або раціональним) і оскільки всі орієнтації мають тенденцію представляти не тільки локаційний центр як соціальної так та особистісної системи, будучи їх складовими частинами, але також ціннісні еталони (які, 
будучи інтерналізовані, стають глибинними змінними, подібними диспозиціям потреб і рольовим очікуванням), ні диспозиції потреб, ні рольові очікування не роблять впливу поза зв'язком їх з певними ціннісними орієнтаціями, з якими вони виявляються послідовно пов'язаними (принаймні в тому сенсі, що як ті, так і інші зумовлюють одні й ті ж орієнтації в певний момент часу). Отже, при розгляді особистостей чи соціальних систем як первинних одиниць для абстрагування диспозицій потреб або рольових очікувань, ми можемо представляти ціннісноорієнтаційні компоненти цих орієнтації, згруповані таким чином, що вони стають ціннісно-орієнтаційними компонентами самих диспозицій потреб або рольових очікувань . Отже, ми отримуємо можливість класифікувати диспозиції потреб та рольові очікування 3 точки зору тих ціннісних орієнтацій, з якими вони мають тенденцію зв'язуватися.

В принципі, отже, кожна конкретна диспозиція потреб особистості, або кожне рольове очікування соціальної структури, включає певну комбінацію цінностей п'яти еталонних змінних. Поєднана класифікація кожної з п'яти 3 кожною іншою, утворює таблицю з тридцяти двох клітин, дає, за умови, що список еталонних змінних $є$ вичерпним, класифікацію основних ціннісних еталонів. Інтерналізовані в систему особистості, ці ціннісні еталони служать відправною точкою для класифікації можливих типів диспозицій потреб; інституційовані в систему соціальної дії вони дають класифікацію компонентів визначень рольових очікувань.

Термін «диспозиція потреб», який використовується тут, завжди включає ряд диспозицій по відношенню до об'єктів. Абстраговане від об'єктів, це поняття стає еліптичним. Тільки для того, щоб уникнути ще більшої громіздкість терміна, тут зазвичай не вживається більш складний вираз: «диспозиція потреб по відношенню до об'єкта». Однак такі диспозиції потреб і окремі об'єкти, які їх задовольняють, надзвичайно різноманітні. Механізм субституції пов'язує диспозицію потреб з різними об'єктами, які насправді не задовольняють іiі.

Класифікація диспозицій потреб і рольових очікувань відповідно до ціннісних еталонів - це тільки частина більш широкої проблеми класифікації диспозицій потреб і рольових очікувань. У загальну картину повинні бути включені інші компоненти дії, перш ніж вдасться отримати класифікацію, адекватну для проблеми аналізу цих систем. Наприклад, один ряд факторів, що входять в диспозиції потреб, - компоненти, обумовлені конституцією організму, - абсолютно навмисно були виключені з цього аналізу. Оскільки ж вони є суттєвими для адекватної класифікації елементів диспозиції потреб особистості, ця класифікація, проведена в рамках еталонних змінних, з очевидністю вимагає доопрацювання.

Слід пояснити, що така класифікація ціннісних компонентів диспозицій потреб і рольових очікувань з точки зору еталонних змінних - перший крок до конструювання динамічної теорії систем дії. Для того, щоб досягти емпіричного 
значення, ця класифікація повинна бути пов'язана 3 функціональними проблемами розвитку систем дії.

Класифікуючи диспозиції потреб та рольові очікування, ми повинні приступити до справи складання суміщеної класифікації таблиць, зазначених вище. При конструюванні цих таблиць ми знайшли, що певні дихотомії еталонних змінних мають більше значення з точки зору диспозицій потреб (і отже систем особистості). А деякі інші дихотомії еталонних змінних мають більше значення для рольових очікувань (і отже, для соціальних систем).

Більш того, еталонні змінні, більш важливі для класифікації диспозицій потреб, - не ті ж самі, які важливі для класифікації рольових очікувань; насправді, ці два набори більш-менш взаємодоповнюючі; ті, які мають більше значення для диспозицій потреб, мають менше значення для рольових очікувань, і навпаки.

Тільки одна еталонна мінлива виявляється однаково придатною, як до потреб диспозиції, так і до рольових очікувань - це змінна орієнтації на себе орієнтації на колектив (номер другий у списку). 3 інших чотирьох перша: ефективність - ефективна нейтральність і п'ята: специфічність - дифузійність виявляються важливими переважно для диспозицій потреб. Третя: універсалізм - партикуляризм і четверта: якість - результативність важливі головним чином для рольових очікувань.

Отже, соціальні системи, як ми вже сказали, - це переважно констеляції ролей або рольових очікувань. Первинні проблеми, пов'язані з рольовими очікуваннями і орієнтаціями, якими вони обумовлюються, такі. 1. У плані орієнтації питання полягає в тому, грунтуються чи ні взаємні рольові відносини одних ролей по відношенню до інших (чи до рольових очікувань, що визначає роль) на пізнавальних або на розпізнавальних еталонах. (Якщо дана роль пов'язана 3 іншою роллю на підставі пізнавальних еталонів, то їі головні характеристики не визначаються ii специфічними відносинами 3 іншими соціальними об'єктами, і тоді їі характеристики не змінюються значно залежно від характеристик тих «інших», з якими вона взаємодіє.) 2 . У плані об'єкта питання полягає в тому, чи пов'язана дана роль 3 іншими ролями на підставі діяльності або якісних характеристик їі носія. Ці дві проблеми первинні, тому що вони стосуються здебільшого основних аспектів взаємовідносин, які мають місце між ролями. Таким чином вибір ролей (або виконавців ролей) відповідно до даних проблемами в певному сенсі формує природу даної соціальної системи.

Соціальна система - це переважно система ролей. Споконвічні проблеми, пов'язані з ролями (які керують взаємними відносинами індивідів всередині соціальної системи), якщо ми маємо справу 3 системою таких ролей: 1) інтегрована дана роль 3 іншими ролями на підставі універсальних або партикулярних принципів організації, 2) визначені чи ні дані ролі - i, отже, співвідносяться вони один з одним - з урахуванням якостей або результативності, 
що характеризують їх виконавців. Слід нагадати, що питання про те, яка роль пов'язана з тим чи іншим аспектом, найчастіше залежить від ціннісних еталонів, інституціональних в даній соціальній системі. Звідси: еталонні змінні найбільш релевантні для опису нормативних моделей, керуючих ролями (тобто рольовими очікуваннями) це якість - результативність та універсалізм - партикуляризм. Виділяються чотири головних типи рольових очікувань, сконструйовані за допомогою подальшого накладення класифікацій для кожного з основних типів рольових очікувань..

Отже, Парсонс стверджував, що кожна дійова особа (актор) націлена на отримання максимального задоволення від скоєної дії і їі результату, і якщо це досягається у взаємодії з іншою дійовою особою, то перший буде прагнути до продовженню дії. Таким чином, кожен індивід приходить до очікування певних дій від інших людей у певних ситуаціях. 3 цих очікувань виникають соціальні правила (норми) і загальноприйняті цінності, що допомагають гарантувати бажаний характер відповідних реакцій. Все це створює систему «рольових статусів», кожному 3 яких пропонується певна очікувана поведінка, а також заохочення і покарання за відповідність чи невідповідність поведінки даним очікуванням. Тому соціальна роль мислиться Т. Парсонсом не просто як сектор конкретної системи дій даного індивіда, але як саме такий сектор в тій мірі, в якій він одночасно і підпорядкований певній сукупності нормативних очікувань на рівні соціальної системи, i пов'язаний 3 сукупністю відносин 3 іншими виконавцями такого типу, що разом вони складають колектив.

В центрі уваги соціологічного аналізу, згідно Т. Парсонса, знаходиться зчленування між нормативними системами, у той час як ролі є компонентами більш «віддаленими» за напрямом особистісним системам, а цінності (норми) компонентами, більш «віддаленими» в бік культурних систем.

Процес засвоєння індивідом соціальних ролей, що здійснюється в ході соціалізації особистості, включає в себе, вважає Т. Парсонс, три основних компоненти. Перший 3 них полягає в інтерналізації (тобто в глибокому внутрішньому засвоєнні) індивідом мотивацій, що конкретизуються у вигляді прийнятних для даного суспільства і даної сукупності ролей в цьому суспільстві орієнтирів поведінки. Другим компонентом цього процесу $\epsilon$ надання суспільством індивіду сприятливих для нього умов діяльності відповідно до продиктованих йому (або обираються їм самим) ролей.

Нарешті, оскільки індивід взаємодіє з іншими людьми в системі колективів, основною умовою їх солідарності є дотримання виконання індивідами належних рівнів лояльності по відношенню до колективних інтересів і потреб.

Т. Парсонс вважав, що саме в процесі соціальної взаємодії виникають і реалізуються соціальні ролі індивідів. А сукупність таких взаємодій, в процесі яких індивіди виконують певні соціальні ролі, $\epsilon$ живою, динамічною, що розвивається тканиною соціальної системи. Тому «в соціальній системі, - 
підкреслював він, - мінімальною одиницею $є$ роль індивідуального діяча (або, якщо завгодно, статус - роль), а мінімальне відношення являє собою стандартизована взаємодія, коли кожен учасник функціонує як діяч, в тій чи іншій мірі орієнтуючись на інших, і навпаки, кожен є об'єктом для всіх інших. Одиницями соціальних систем більш високого порядку є колективи, тобто організовані системи дії, що характеризуються виконанням ролей множиною людських індивідів.

\section{СПИСОК ВИКОРИСТАНИХ ДЖЕРЕЛ}

Балабанова Е.С. Социально-экономическая зависимость и социальный паразитизм: стратегии «негативной» адаптации // Социологические исследования, 1999, № 4.

Дарвин Ч. Происхождение видов. - М., 1939. 4.

Дарендорф. Класс и классовый конфликт в индустриальном обществе, http://www.vevivi.ru/best/Sotsiologiya-religii-kontseptsiya-YE-Dyurkgeimaref68172. html

Мертон Р. Социальная теория и социальная структура // Социологические исследования, 1992, № 2-4.

Осипов Г.В. Социология и социализм. - М.: Наука, 1990. 14.

Парсонс Т. Система координат действия и общая теория систем действия: культура, личность и место социальных систем // Американская социологическая мысль: М. 1996.

Парсонс Т. О структуре социального действия. - М.: Академический Проект, 2000. - 880 с. Штомпка П. Социология: Анализ современного общества, 2005. http://www.srinest.com/book851_chapter_22_2._Formalnaja_soiologija_G. Zimme lja.html

АЛЕКСАНДР САГАЛАКОВ аспирант Мелитопольский государственны педагогический университет им. Богдана Хмельниикого e-mail:sagalackov@gmail.com

\section{ТЕОРИЯ СОЦИАЛЬНЫХ РОЛЕЙ В КОНЦЕПЦИИ СОЦИАЛЬНОГО ВЗАИМОДЕЙСТВИЯ Т. ПАРСОНСА И ЕГО ВЛИЯНИЕ НА ИЗУЧЕНИЕ СОЦИАЛЬНОЙ АДАПТАЦИИ ЛИЧНОСТИ}

В статье раскрывается понятие социальной роли по Парсонсу. Автор подчеркивает, что роли у Парсонса институциональные, если полностью согласуются с установленными культурными образцами, причем выделение роли актера со всей системы его личности делает возможным анализ взаимосвязи личности с социальными системами. Автор отмечает, что процесс усвоения индивидом социальных ролей, который происходит в ходе социализации личности по Парсонсу, включает в себя три основных компонента. Первый из них состоит в виде принятой для данного общества и данной совокупности ролей в этом обществе ориентиров поведения. Второй - есть предоставление обществом индивиду благоприятных для него условий деятельности в соответствии к продиктованными ему (или обираются им самим) ролями. Третий - есть соблюдение выполнения индивидами надлежащих уровней лояльности по отношению к коллективным интересам и потребностям. То есть Т.Парсонс считает, что 
именно в процессе социального взаимодействия возникают и реализуются социальные роли индивидов.

Ключевые слова: социальная роль; социальная структура; институционализация; социальная система; диспропорции нужд; ролевые ожидания; интернализация.

\section{OLEKSANDR SAGALAKOV Post-graduate student of Bogdan Khmelnitsky Melitopol State Pedagogical University e-mail:sagalackov@gmail.com}

\section{THE THEORY OF SOCIAL ROLES IN THE T. PARSONS' CONCEPT OF SOCIAL INTERACTION AND ITS IMPACT ON THE STUDY OF SOCIAL ADAPTATION OF THE INDIVIDUAL}

The article reveals the concept of the social role according to Parsons. The author emphasizes that the roles according to Parsons are institutional if they are fully consistent with the established cultural patterns, and the allocation of the role of an actor from the entire system of his personality makes it possible to analyze the connections between personality and social systems. But problems of personality and social structure can be investigated only when these concepts differ. The author notes that the roles, and not the personality, are the units of the social structure according to Parsons.But since the order of individual reactions is essential to maintain the stability of a certain sector of the social system, there are some "control mechanisms" to keep the potential variety of actor responses within narrower limits. And since an actor is the element of the social system, then the social structure is a system of standardized relations of actors, performing roles relative to each other. The author notes that Parsons' main structural element of social systems is the structure of institutional standards that determine the roles of actors in it, that is, institutions are understood as factors controlling human activities in society. The author emphasizes that the process of assimilating by the individual of social roles, carried out in the course of personalization of Parsons' personality, includes three main components. The first one is the internalisation of individual motivations, which are specified in the form of guidelines of behavior acceptable for a certain society and certain of roles in this society. The second one is the provision by the society of an individual favorable conditions to work in accordance with the roles of individual person dictated to him (or elected by him). The third one is the compliance with the fulfillment by individuals of appropriate levels of loyalty in relation to collective interests and needs. That is, T. Parsons believed that the social roles of individuals arise and are realized precisely in the process of social interaction.

Key words: social role; social structure; institutionalization; social system; imbalances in needs; role expectations; internalization

\section{REFERENCES}

Balabanova E.S.(1999). Sotsialno-ekonomicheskaya zavisimost i sotsialnyiy parazitizm: strategii «negativnoy» adaptatsii // Sotsiologicheskie issledovaniya, №4.

Darvin Ch.(1939). Proishozhdenie vidov. - M., 1939.

Darendorf. (2013). Klass i klassovyiy konflikt v industrialnom obschestve, http://www.vevivi.ru/best/Sotsiologiya-religii-kontseptsiya-YE-Dyurkgeimaref68172. html Merton R. (1992). Sotsialnaya teoriya i sotsialnaya struktura. Sotsiologicheskie issledovaniya, № 24. 
ISSN 2410-3381 (PRINT), ISSN 2520-6842 (ONLINE)

Osipov G.V. (1990). Sotsiologiya i sotsializm. - M.: Nauka. № 14.

Parsons T. (1996). Sistema koordinat deystviya i obschaya teoriya sistem deystviya: kultura, lichnost i mesto sotsialnyih sistem // Amerikanskaya sotsiologicheskaya myisl: M.

Parsons T. O(2000). strukture sotsialnogo deystviya. — M.: Akademicheskiy Proekt, 880 s. Shtompka P. (2005). Sotsiologiya: Analiz sovremennogo obschestva, http://www.srinest.com/book851_chapter_22_2._Formalnaja_soiologija_G. Zimme lja.html

\section{Надійшла до редакції 25.11.2019}

